\title{
Optimization of ultrasound assisted extraction of functional ingredients from Stevia rebaudiana Bertoni leaves
}

\author{
Jana Šic Žlabur ${ }^{1}$, Sandra Voća ${ }^{1}$, Nadica Dobričević1, Mladen Brnčićc* ${ }^{2}$, Filip Dujmić2, \\ and Suzana Rimac Brnčić ${ }^{2}$ \\ ${ }^{1}$ Faculty of Agriculture, University of Zagreb, Svetošimunska cesta 25, Zagreb, Croatia \\ ${ }^{2}$ Faculty of Food Technology and Biotechnology, University of Zagreb, Pierottijeva 6, Zagreb, Croatia
}

Received November 13, 2014; accepted January 6, 2015

\begin{abstract}
A b s t r a c t. The aim of the present study was to reveal an effective extraction procedure for maximization of the yield of steviol glycosides and total phenolic compounds as well as antioxidant activity in stevia extracts. Ultrasound assisted extraction was compared with conventional solvent extraction. The examined solvents were water $\left(100^{\circ} \mathrm{C} / 24 \mathrm{~h}\right)$ and $70 \%$ ethanol (at $70^{\circ} \mathrm{C}$ for $30 \mathrm{~min}$ ). Qualitative and quantitative analyses of steviol glycosides in the extracts obtained were performed using high performance liquid chromatography. Total phenolic compounds, flavonoids, and radical scavenging capacity by 2, 2-azino-di-3-ethylbenzothialozine-sulphonic acid) assay were also determined. The highest content of steviol glycosides, total phenolic compounds, and flavonoids in stevia extracts were obtained when ultrasound assisted extraction was used. The antioxidant activity of the extracts was correlated with the total amount of phenolic compounds. The results indicated that the examined sonication parameters represented as the probe diameter ( 7 and $22 \mathrm{~mm}$ ) and treatment time $(2,4,6,8$, and $10 \mathrm{~min})$ significantly contributed to the yield of steviol glycosides, total phenolic compounds, and flavonoids. The optimum conditions for the maximum yield of steviol glycosides, total phenolic compounds, and flavonoids were as follows: extraction time $10 \mathrm{~min}$, probe diameter $22 \mathrm{~mm}$, and temperature $81.2^{\circ} \mathrm{C}$.

$\mathrm{K}$ e y w o r d s: sonication, stevia, steviol glucosides, phenolic compounds, extruction efficiency
\end{abstract}

\section{INTRODUCTION}

Stevia rebaudiana Bertoni leaves are natural source of diterpenic glycosides: stevioside, steviolbioside, rebaudioside (A, B, C, D, E, F), and dulcoside A (O'Brien-Nabors, 2012), known as steviol glycosides, which are traditionally used as non-caloric sweeteners (Sekaran et al., 2007). Among the different steviol glycosides, the most abundant is stevioside (4-20\%) followed by rebaudioside A (1-3\%) and other steviol glycosides (Geuns, 2003). Despite the significant amount of sweetness, steviol glycosides do not have any caloric value and therefore the stevia plant has found widespread use as a sweetener that is primarily suitable for diabetics (Puri et al., 2011). Glycosides show significant antioxidant activity (Shukla et al., 2012; Criado et al., 2014). Besides glycosides, stevia leaves contain a significant amount of phenolic compounds, which contribute to overall antioxidant activity (Abou-Arab et al., 2010; Barba et al., 2014a; Lemus-Mondaca et al., 2012).

Hence, various ranges of extraction techniques are in use for extraction of steviol glycosides, but still, conventional solvent extraction is the most commonly applied method (Puri et al., 2012). In recent times, significant development of modern extraction techniques such as ultrasound assisted extraction (UAE), microwave assisted extraction, enzyme assisted extraction, and supercritical fluid extraction have emerged (Barba et al., 2015; Khoddami, et al., 2013; Krishnaswamy et al., 2013; Miron et al., 2013, Piasecka et al., 2014; Puri et al., 2012). Ultrasound assisted extraction has numerous advantages, primarily because of the equipment flexibility, easy handling, and cost effectiveness in combination with a shorter treatment time, reduction of temperatures, high reproducibility, improvement in mass transfer, and the eco-friendly approach (Barba et al., 2014b; Brnčić et al., 2009). Ultrasound introduced as a technique in a liquid medium relies on the mechanism of cavitation. Ultrasound wave propagation in a liquid causes extreme effects, especially, if the treated liquid is propagated with ultrasonic waves under low frequencies between $20 \mathrm{kHz}$ 
T a b l e 1. Experimental conditions

\begin{tabular}{|c|c|c|c|c|}
\hline Extraction technique & Solvent & Solvent volume (ml) & Time (min) & Probe diameter $(\mathrm{mm})$ \\
\hline Conventional & Distilled water & \multirow{2}{*}{200} & $60 \times 24$ & - \\
\hline \multirow[t]{5}{*}{ Conventional } & \multirow[t]{5}{*}{ Ethanol $(70 \% \mathrm{v} / \mathrm{v})$} & & 30 & - \\
\hline & & \multirow{10}{*}{200} & 2 & 7 \\
\hline & & & 4 & 7 \\
\hline & & & 6 & 7 \\
\hline & & & 8 & 7 \\
\hline \multirow{6}{*}{ UAE } & \multirow{6}{*}{ Distilled water } & & 10 & 7 \\
\hline & & & 2 & 22 \\
\hline & & & 4 & 22 \\
\hline & & & 6 & 22 \\
\hline & & & 8 & 22 \\
\hline & & & 10 & 22 \\
\hline
\end{tabular}

and $100 \mathrm{kHz}$ usually called power ultrasound. As a result of such propagation, alternating high pressure, cycles that cause compression of the cavitational bubbles, and low pressure that causes rarefaction of the cavitational bubbles occur. Within those bubbles, the conditions are possible to reach temperatures up to $5000 \mathrm{~K}$ and the pressures - a maximum of $50 \mathrm{MPa}$ (Brnčić et al., 2010; Dujmić et al., 2013; Lagnika et al., 2014). After numerous repeats of the cycles, cavitational bubbles implode and deliver their energy to the environment. The first influence of the cavitational bubble on the system is mechanical due to formation of liquid jets. Secondly, there is a thermal effect as a consequence of the implosion of the bubbles and spreading out of the heat and pressures. As a result of such disturbances caused by power ultrasound, the cell walls of the plants are damaged or completely disrupted and the mass transfer of extractable compounds is accelerated (Cvjetko Bubalo et al., 2013).

It is important to emphasize the benefits of power ultrasound application ie the significant increase in the yield rate irrespective of the solvent type, which gives a great advantage of replacement of organic solvents with water (Pingret et al., 2012). Optimized power ultrasound treatment does not affect some bioactive compounds in ultrasound treated food products (Dai and Mumper, 2010; Ignat et al., 2011). In addition, utilization of power ultrasound is appropriate for extraction of compounds with a varied chemical structure (Šic Žlabur et al., 2012) and is characterized as nonthermal technology with an increase in temperature of $1-2^{\circ} \mathrm{C}$ per minute without cooling of the treated sample (Knorr et al., 2004).
The main objective of this study was to determine differences in the extraction efficiency of different techniques on stevioside and rebaudioside A yield as well as on total phenolic compounds and antioxidant activity in stevia extracts.

\section{MATERIALS AND METHODS}

Stevia plants were cultivated on the experimental field from seedlings and harvested during the flowering of the plants in late September (2012). Fresh, green stevia leaves were dried in a convection dryer (Inko ST40T, Croatia) in an elemental layer at $55^{\circ} \mathrm{C}$ for 2 hours. Dried stevia leaves were milled in laboratory mill (IKA MF-10, Germany) to increase the surface area for proper mixing with the solvent. The experimental conditions of the different extraction techniques are shown in Table 1.

Two solvents (water and 70\% ethanol) for conventional solvent extraction of green stevia powder were used. The extraction with water as a solvent was carried out as follows: $500 \mathrm{mg}$ of the stevia sample was placed in a flask and $200 \mathrm{ml}$ of distilled water $\left(100^{\circ} \mathrm{C}\right)$ was added. The mixture was left for $24 \mathrm{~h}$ with agitation on the magnetic mixer. After extraction was completed, the extracts obtained were vacuum-filtered and used for chemical analysis. Extraction with ethanol was performed according to Lavini et al. (2008) with some modifications: $500 \mathrm{mg}$ of the stevia sample was placed in a flask and $200 \mathrm{ml}$ of $70 \%(\mathrm{v} / \mathrm{v})$ ethanol was added. The mixture was kept in a water bath at $70^{\circ} \mathrm{C}$ for $30 \mathrm{~min}$ with stirring. The extracts obtained were vacuum-filtered. The prepared extract was used for further analysis. 
Ultrasound assisted extraction (UAE) was carried out with an ultrasound probe system. The power ultrasound device consisted of a transducer for converting electric signals into ultrasonic waves and a probe with a specific diameter. The maximal nominal output power of the device (UP 400S, Hielscher Company, Teltow, Germany) was $400 \mathrm{~W}$ and the ultrasonic frequency was $24 \mathrm{kHz}$. The coupling of the 2 ultrasound variables was investigated and applied during sonication: treatment time $(2,4,6,8$, and $10 \mathrm{~min})$ as well as 2 different probe diameters ( 7 and $22 \mathrm{~mm}$ ). The propagation of power ultrasound waves was continuous and the amplitude was $100 \%$ of nominal output power (maximum). During sonication of the samples, the temperature change was measured every $30 \mathrm{~s}$ with a laser thermometer (Raytek-MiniTemp FS, USA). After the ultrasound treatment, the extracts obtained were vacuum-filtered and used for analysis.

The content and composition of steviol glycosides were analysed using HPLC. The Varian 920 LC with Galaxie software (Varian) was used in conjunction with a multiple UV wavelength detector and auto-injector, autosampler, and quaternary pump. Separation was done in an Nucleosil C-18, $5 \mu \mathrm{m}(250 \times 4.6 \mathrm{~mm}$ I.D. $)$ with a Nucleosil C-18, guard column, $5 \mu \mathrm{m}(10 \times 4.6 \mathrm{~mm}$ I.D. $)$. To optimize the separation of aqueous stevia extracts, HPLC operating conditions incorporated a gradient mobile phase: $\mathrm{A}$ - water (HPLC grade), $\mathrm{pH} 5$ adjusted with acetic acid; $\mathrm{B}$ - acetonitrile (HPLC grade) $\mathrm{pH} 5$. The following gradient elution was used for the separation of stevioside and rebaudioside A: elution started with $80 \% \mathrm{~A}$ and $20 \% \mathrm{~B}$, which remained the linear gradient until $20 \mathrm{~min}$. From 20-25 min, elution was kept isocratic with $20 \% \mathrm{~A}$ and $80 \% \mathrm{~B}$. A linear gradient was then used to reach $80 \% \mathrm{~A}$ and $20 \% \mathrm{~B}$ until $28 \mathrm{~min}$. The operating conditions were as follows: flow rate $1.0 \mathrm{ml} \mathrm{min}^{-1}$, column temperature $20^{\circ} \mathrm{C}$, and injection volume $10 \mu \mathrm{l}$ of the standards and extract samples. The UV detector was set to monitor at $210 \mathrm{~nm}$ with a reference signal set at $360 \mathrm{~nm}$. For quantification purposes, stevioside (98\% purity) and rebaudioside A (96\% purity) standards were obtained from Sigma Aldrich (Germany). Standard solutions of 0.10, 0.25, $0.5,0.75$, and $1.0 \mathrm{~g} \mathrm{l}^{-1}$ were prepared for both stevioside and rebaudioside A in water (HPLC grade) providing five calibration points. The final content of stevioside and rebaudioside $\mathrm{A}$ in the analyzed aqueous extracts of stevia green powder was expressed as $\mathrm{mg} \mathrm{g}^{-1}$ of the aqueous extract.

The total phenolic content of the stevia extracts were measured at $750 \mathrm{~nm}$ by the Folin-Ciocalteu reagent (Shukla et al., 2012). The measurement was carried out as follows: $1 \mathrm{ml}$ of the extract and $1 \mathrm{ml}$ of the Folin-Ciocalteu reagent diluted with distilled water $(1: 2)$ were added in a volumetric flask with a volume of $50 \mathrm{ml}$ and allowed to stand for $3 \mathrm{~min}$. Additionally, $3 \mathrm{ml}$ of a saturated sodium carbonate solution was added, the flask was filled to the mark with distilled water and allowed to stand for $3 \mathrm{~h}$ at room tempe- rature with intermittent shaking. The flavonoid content of the extracts obtained was measured by the Folin-Ciocalteu reagent (Abou-Arab and Abou-Salem, 2010): $1 \mathrm{ml}$ of the prepared aqueous extracts, $1 \mathrm{ml}$ of $20 \% \mathrm{HCl}(\mathrm{v} / \mathrm{v})$, and $0.5 \mathrm{ml}$ formaldehyde were added in the volumetric flask with a volume of $25 \mathrm{ml}$. The prepared samples were blown with nitrogen $\left(\mathrm{N}_{2}\right)$ and allowed to stand for $24 \mathrm{~h}$ at room temperature in a dark place. After $24 \mathrm{~h}$, the same Folin-Ciocalteu reaction as for total phenols was made. The absorbance of the blue colour that developed for the analysis of total phenols and flavonoid composition of the stevia extracts was measured spectrophotometrically (Shimadzu UV 1650 PC) at $750 \mathrm{~nm}$ with distilled water as a blank probe. Nonflavonoid content was expressed as the difference between total phenols and flavonoids. Gallic acid was used as an external standard and the concentration of total phenolic, flavonoid, and non-flavonoid content was expressed as $\mathrm{mg} \mathrm{g}^{-1}$ of the extract.

The antioxidant activity of the stevia extracts was determined by the ABTS method. Trolox (6-hydroxy-2,5,7,8tetramethylchroman-2-carboxylic acid; SigmaAldrich) was used as an antioxidant standard. Trolox $(2.5 \mathrm{mM})$ was prepared in ethanol $(80 \%)$ for use as a stock standard. ABTS, 2, 2'-azinobis (3-ethylbenzothiazoline-6-sulfonic acid), and potassium persulfate were obtained from Sigma-Aldrich. The experiments were performed according to Miller et al. (1993). ABTS (7 mM) and potassium persulfate (140 $\mathrm{mM}$ ) were dissolved in distilled water. These two solutions ie $88 \mu \mathrm{l}$ prepared potassium persulfate $(140 \mathrm{mM})$ and $5 \mathrm{ml}$ prepared ABTS solution were mixed and the mixture was allowed to stand in the dark at room temperature for $16 \mathrm{~h}$ before use in order to produce ABTS radicals (ABTS $\bullet+$ ). On the day of analysis, $1 \%$ ABTS solution ( $1 \mathrm{ml}$ ABTS in the volumetric flask of $100 \mathrm{ml}$ and filled with $96 \%$ ethanol to the mark) was prepared. For the study, the absorbance of the ABTS radical solution was measured at $734 \mathrm{~nm}$ and set to absorbance of $0.70 \pm 0.02 .160 \mu \mathrm{l}$ of the extracts obtained were directly injected in the cuvette, mixed with $2 \mathrm{ml} 1 \%$ ABTS •+, and absorbance at $734 \mathrm{~nm}$ was measured.

The experiments were performed in triplicate. Statistical analyses of the results obtained were performed using the SAS ${ }^{\circledR}$ version 9.3 (SAS, 2010). Data were subjected to the one-way analysis of variance (ANOVA) for comparison of results obtained by the conventional extraction techniques and UAE. Two-factorial analysis of variance (ANOVA) for comparison of the influence of the ultrasound parameters (extraction time and probe diameter) was performed. Mean values were compared by the t-test (LSD), and they were considered significantly different at $\mathrm{p} \leq 0.001$.

\section{RESULTS AND DISCUSSION}

The comparison results of the extraction yields of steviol glycosides (stevioside and rebaudioside A) and the total phenol content including the flavonoid and non-flavonoid content ( $\mathrm{mg} \mathrm{g}^{-1}$ extract) from the stevia samples 
T a b l e 2. The content of stevioside, rebaudioside A, total phenols, flavonoids, and non-flavonoids ( $\mathrm{mg} \mathrm{g}^{-1}$ extract) as well as antioxidant activity (mM Trolox) in ethanol and aqueous stevia extracts obtained by the conventional extraction

\begin{tabular}{|c|c|c|c|c|c|c|}
\hline Solvent & Stevioside & Rebaudioside A & Total phenols & Flavonoids & Non-flavonoids & $\begin{array}{l}\text { Antioxidant } \\
\text { activity }\end{array}$ \\
\hline Water & $74.72 b \pm 0.01$ & $22.26 b \pm 0.02$ & $53.96 \mathrm{~b} \pm 0.92$ & $35.82 \mathrm{~b} \pm 0.32$ & $18.11 \pm 0.48$ & $2.10 \mathrm{~b} \pm 1.06$ \\
\hline Ethanol & $82.68 \mathrm{a} \pm 0.01$ & $24.39 \mathrm{a} \pm 0.01$ & $56.72 \mathrm{a} \pm 1.02$ & $37.94 a \pm 0.20$ & $18.78 \pm 0.53$ & $2.24 \mathrm{a} \pm 1.11$ \\
\hline
\end{tabular}

Different letters indicate significant differences between means at $\mathrm{p}<0.001$, for non-flavonoids - not significant.

extracted with the conventional (water, ethanol) method and UAE are listed in Table 2. Significant statistical differences $(p<0.001)$ in the content of stevioside, rebaudioside $\mathrm{A}$, and total phenols depending on the extraction technique were determined. A higher content of steviol glycosides was found during the conventional extraction using ethanol with recorded stevioside content of $82.68 \mathrm{mg} \mathrm{g}^{-1}$ extract than that in aqueous extracts $\left(74.72 \mathrm{mg} \mathrm{g}^{-1}\right.$ extract). The alcoholic solution in combination with higher ambient temperatures and agitation were reported more efficient for ex traction of different compounds from plants (Mustafa and Turner, 2011). Stevioside was the major component in all the examined extracts followed by rebaudioside A but not in same proportions. The composition of the steviol glycosides varied according to both the extraction procedure and the type of the solvent as well. In addition, higher total phenol content was found in the ethanolic solutions compared to the aqueous extracts. The flavonoid content was higher compared to that of non-flavonoids. These results were in close agreement with the results found in the literature (Abou-Arab and Abou-Salem, 2010; Puri et al., 2011).

Furthermore, the impact of two parameters (probe diameter and duration) during UAE on the contents of total phenols, flavonoids, and non-flavonoids, as well as antioxidant capacity was investigated. Extracts obtained by UAE treated with the ultrasonic probe with a 7- and 22-mm diameter and extraction time longer than 8 min exhibited statistically higher contents of total phenols, flavonoids, and non-flavonoids, as well as higher radical scavenging capacity. The antioxidant activity of plant species is directly correlated with the composition of vitamins and different phenolic phytochemicals such as flavonoids, glycosides, alkaloids, and hydroxycinnamic acids (Zayova et al., 2013). The antioxidant capacities of the extracts are presented in Tables 2 and 3 . The antioxidant capacity was significantly different $(p<0.001)$ depending on the extraction technique applied. The antioxidant capacity measured by the ABTS assay highly correlated with total phenolics and that is confirmed by the results obtained. Namely, extracts with higher content of total phenols (including flavonoids) but also higher content of steviol glycosides showed higher values of antioxidant capacity. It has been previously reported that glycosides and phenols, compounds that are characteristic for the stevia composition, have a large number of $-\mathrm{OH}$ groups, which contribute to their antioxidative action (Leja et al., 2007; O’Brien-Nabors, 2012).

The increased content of stevioside and rebaudioside A was determined in extracts obtained by UAE, treated using the 22-mm diameter ultrasonic probe, and extracted for more than $6 \mathrm{~min}$. The highest stevioside $\left(96.48 \mathrm{mg} \mathrm{g}^{-1}\right.$ extract) and rebaudioside A contents (36.92 $\mathrm{mg} \mathrm{g}^{-1}$ extract) were determined in the ultrasonic treated samples for $10 \mathrm{~min}$ with the $22-\mathrm{mm}$ diameter sonotrode. There was a twofold increase in the rebaudioside A content depending on the sonotrode used. The results of stevioside, rebaudioside A, total phenol, flavonoid, and non-flavonoid content obtained in the stevia extracts suggest that the studied ultrasound parameters (extraction time and sonotrode diameter) significantly influenced their composition $(\mathrm{p}<0.001)$. The present study showed that the antioxidant activity positively correlated with the ultrasound treatment. The ultrasound extraction processing technique is characterized by several parameters: amplitude, power, frequency, extraction rate, and attenuation coefficient (Butz and Tauscher, 2002). UAE in this work showed a higher extraction yield of total phenols with a shorter extraction time compared to the conventional extractions. After only $10 \mathrm{~min}$ of sonication, the highest total phenol content was $77.89 \mathrm{mg} \mathrm{g}^{-1}$ of the extract. Also, the high temperature which is applied during the conventional aqueous extraction contributes to degradation of thermosensitive compounds such as phenolic compounds (Ross et al., 2009).

During the UAE, the temperature change was measured. Temperature that develops during ultrasonic extraction is a very important parameter in optimization of ultrasonic treatment with the aim of increasing the extraction yield of phenolic compounds (Dai and Mumper, 2010; Dent et al., 2013). During the UAE with the smaller diameter probe (7 $\mathrm{mm}$ ) for 2-10 $\mathrm{min}$, the highest measured temperature was $45.5^{\circ} \mathrm{C}$ (Fig. 1), while during the ultrasonic extraction using the $22-\mathrm{mm}$ diameter probe for the same extraction time, the highest measured temperature was $81.2^{\circ} \mathrm{C}$ (Fig. 1). The temperature rise in the system during UAE extraction is expected and it exhibits a positive correlation with the 


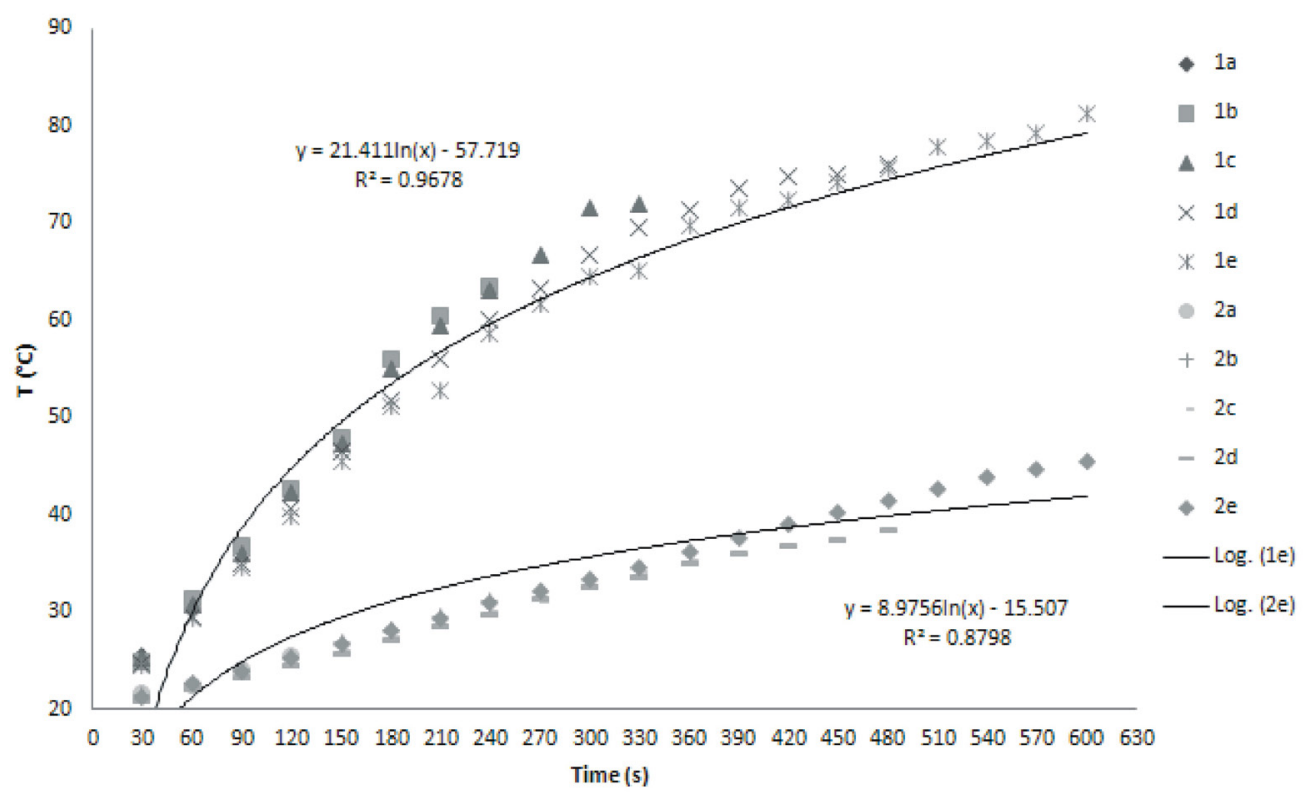

Fig. 1. Temperature increase $\left({ }^{\circ} \mathrm{C}\right)$ during UAE with the $7 \mathrm{~mm}$ diameter probe (samples: $2 \mathrm{a}, 2 \mathrm{~b}, 2 \mathrm{c}, 2 \mathrm{~d}, 2 \mathrm{e}$ ) and the $22 \mathrm{~mm}$ diameter probe (samples: 1a, 1b, 1c, 1d, 1e).

T a b l e 3. The content of stevioside, rebaudioside A, total phenols, flavonoids, and non-flavonoids ( $\mathrm{mg} \mathrm{g}^{-1}$ extract) as well as antioxidant activity (mM Trolox) in aqueous stevia extracts obtained by UAE

\begin{tabular}{|c|c|c|c|c|c|c|c|}
\hline \multicolumn{2}{|c|}{$\begin{array}{l}\text { High intensity } \\
\text { ultrasound }\end{array}$} & \multirow{2}{*}{ Stevioside } & \multirow{2}{*}{$\begin{array}{c}\text { Rebaudioside } \\
\text { A }\end{array}$} & \multirow{2}{*}{ Total phenols } & \multirow{2}{*}{ Flavonoids } & \multirow{2}{*}{ Non-flavonoid } & \multirow{2}{*}{$\begin{array}{l}\text { Antioxidant } \\
\text { activity }\end{array}$} \\
\hline $\mathrm{T}(\min )$ & PD (mm) & & & & & & \\
\hline 2 & 7 & $51.12 \mathrm{j} \pm 0.08$ & $3.92 \mathrm{j} \pm 0.01$ & $24.60 \mathrm{j} \pm 1.39$ & $18.45 \mathrm{j} \pm 0.6$ & $6.15 \mathrm{~h} \pm 0.94$ & $1.57 \mathrm{j} \pm 1.88$ \\
\hline 4 & 7 & $55.40 \mathrm{i} \pm 0.02$ & $7.56 \mathrm{i} \pm 0.03$ & $35.21 \mathrm{~h} \pm 2.16$ & $26.05 \mathrm{~h} \pm 3.19$ & $9.16 \mathrm{f} \pm 0.865$ & $1.90 \mathrm{~h} \pm 0.68$ \\
\hline 6 & 7 & $57.89 \mathrm{~h} \pm 0.03$ & $10.75 \mathrm{~h} \pm 0.25$ & $51.68 \mathrm{f} \pm 0.82$ & $39.24 \mathrm{f} \pm 1.05$ & $12.44 \mathrm{e} \pm 0.64$ & $2.14 \mathrm{~g} \pm 0.55$ \\
\hline 8 & 7 & $60.04 \mathrm{~g} \pm 0.16$ & $13.28 \mathrm{f} \pm 0.25$ & $56.32 \mathrm{e} \pm 0.29$ & $42.90 \mathrm{e} \pm 2.77$ & $13.42 \mathrm{~d} \pm 1.51$ & $2.23 \mathrm{e} \pm 4.89$ \\
\hline 10 & 7 & $65.00 \mathrm{f} \pm 0.01$ & $18.24 \mathrm{f} \pm 0.01$ & $59.43 \mathrm{~d} \pm 2.11$ & $45.76 \mathrm{~d} \pm 2.13$ & $13.67 \mathrm{~d} 0.39$ & $2.34 c \pm 0.67$ \\
\hline 2 & 22 & $76.52 \mathrm{e} \pm 0.67$ & $19.40 \mathrm{c} \pm 0.02$ & $30.68 \mathrm{i} \pm 0.37$ & $22.70 \mathrm{i} \pm 0.76$ & $7.89 \mathrm{~g} \pm 0.26$ & $1.79 \mathrm{i} \pm 3.00$ \\
\hline 4 & 22 & $80.72 \mathrm{~d} \pm 0.02$ & $24.68 \mathrm{~d} \pm 0.47$ & $38.39 \mathrm{~g} \pm 2.77$ & $29.18 \mathrm{~g} \pm 2.07$ & $9.21 \mathrm{f} \pm 0.33$ & $2.20 \mathrm{f} \pm 4.25$ \\
\hline 6 & 22 & $90.40 \mathrm{c} \pm 0.01$ & $26.18 \mathrm{c} \pm 0.01$ & $75.58 \mathrm{c} \pm 0.43$ & $58.19 \mathrm{c} \pm 2.51$ & $17.39 \mathrm{a} \pm 0.45$ & $2.30 \mathrm{~d} \pm 2.39$ \\
\hline 8 & 22 & $93.28 \mathrm{~b} \pm 0.20$ & $28.04 \mathrm{~b} \pm 0.04$ & $76.49 \mathrm{~b} \pm 2.14$ & $60.12 b \pm 2.19$ & $16.37 \mathrm{~b} \pm 0.55$ & $2.41 \mathrm{~b} \pm 3.41$ \\
\hline 10 & 22 & $96.48 \mathrm{a} \pm 0.30$ & $36.92 \mathrm{a} \pm 0.09$ & $77.89 \mathrm{a} \pm 2.28$ & $62.48 \mathrm{a} \pm 3.63$ & $15.41 \mathrm{c} \pm 0.52$ & $2.58 \mathrm{a} \pm 1.84$ \\
\hline
\end{tabular}

$\mathrm{INT}=\mathrm{T}$ X PD: interaction of high intensity ultrasound variables, time (T) and probe diameter (PD). Different letters indicate significant differences between means at $\mathrm{p}<0.001$.

applied ultrasound parameters: amplitude (\%), the diameter of the ultrasonic probe, and extraction time. The most intense temperature rise was recorded in the first six minutes of extraction, regardless of the probe diameter that was used. Based on the comparison of the results of the content of phenolic compounds (Table 3) and temperatures that develops during ultrasonic extraction (Fig. 1), it can be concluded that the temperature rise of almost $50 \%$, depending of the probe diameter that was used, did not cause degradation of the phenolic compounds in the analyzed extracts.
Tiwari et al. (2008) also reported that ultrasound treatment did not cause degradation of bioactive compounds during extraction. Steviol glycosides stability depends on temperature and time. Chang and Cook (1983) reported that only 66 and $38.2 \%$ of the original content of stevioside was determined after heating in an aqueous solution at $100^{\circ} \mathrm{C}$ after 48 and $66 \mathrm{~h}$, respectively. Stevioside showed good stability up to $120^{\circ} \mathrm{C}$ for $1 \mathrm{~h}$, whilst at temperatures exceeding $140^{\circ} \mathrm{C}$ forced decomposition and total decomposition occurred by heating to $200^{\circ} \mathrm{C}$ (Kroyer, 1999). 
From the results obtained, it could be concluded that UAE shows numerous advantages in extraction of valuable compounds from stevia samples in comparison with conventional techniques: a shorter extraction time, higher extraction efficiency and antioxidant capacity of extracts, lower treatment temperature, and easily carried out technique of extraction. It is important to emphasize one more benefit of the ultrasound treatment: no evaporation of a huge amount of solvent or complete replacement of organic solvents with water, showing a significant step forward in the protection of the natural environment and its resources.

\section{CONCLUSIONS}

1. Ultrasound assisted-extraction of functional ingredients from Stevia rebaudiana Bertoni leaves resulted in higher extraction yields of steviol glycosides and phenolic compounds in comparison with the conventional methods.

2. Moreover, it can be concluded that ultrasound assisted extraction shortened the time of extraction of steviol glycosides and phenolic compounds.

3. The optimum conditions for the maximum yield of steviol glycosides, total phenols and flavonoids were as follows: extraction time $10 \mathrm{~min}$, sonotrode diameter $22 \mathrm{~mm}$, and temperature $81.2^{\circ} \mathrm{C}$.

4. Ultrasound assisted extraction could be used as an environmental friendly method of extraction due to reduced operational time, reduced energy consumption, and use of water as a solvent.

\section{REFERENCES}

Abou-Arab A.E. and Abu-Salem M.F., 2010. Evaluation of bioactive compounds of Stevia rebaudiana leaves and callus. Afr. J. Food Sci., 4, 627-634.

Abou-Arab A.E., Abou-Arab A.A., and Abu-Salem M.F., 2010. Physico-chemical assessment of natural sweeteners stevioside produced from Stevia rebaudiana Bertoni plant. Afr. J. Food Sci., 4, 269-281.

Barba F.J., Esteve M.J., and Frígola A., 2014a. Bioactive components from leaf vegetable products. Stud. Nat. Prod. Chem., 41, 321-346.

Barba F.J., Grimi N., Negm M., Quilez F., and Vorobiev E., 2014b. Green recovery technology of sweeteners from Stevia rebaudiana Bertoni leaves. In: Leaf Sweeteners: Resources, Processing and Health Effects (Ed. Wenbiao $\mathrm{Wu}$ ). Nova Science Publishers, New York, USA.

Barba F.J., Grimi N., and Vorobiev E., 2015. Evaluating the potential of cell disruption technologies for green selective extraction of antioxidant compounds from Stevia rebaudiana Bertoni leaves. J. Food Eng., 149, 222-228.

Brnčić M., Karlović S., Rimac Brnčić S., Penava A., Bosiljkov T., Ježek D., and Tripalo B., 2010. Textural properties of infra red dried apple slices as affected by high power ultrasound pre-treatment. Afr. J. Biotechnol., 9, 6907-6915.

Brnčić M., Tripalo B., Penava A., Karlović D., Ježek D., Vikić Topić D., Karlović S., and Bosiljov T., 2009. Applications of Power Ultrasound for Foodstuffs Processing. Croat. J. Food Technol. Biotechnol. Nutr., 1-2, 32-37.
Butz P. and Tauscher B., 2002. Emerging technologies: chemical aspects. Food Res. Int., 35, 279-284.

Chang S.S. and Cook J.M., 1983. Stability studies of Stevioside and Rebaudioside A in Carbonated Beverages. J. Agric. Food Chem., 31, 409-412.

Criado M.N., Barba F.J., Frígola A., and Rodrigo D., 2014. Effect of Stevia rebaudiana on oxidative enzyme activity and its correlation with antioxidant capacity and bioactive compounds. Food Bioprocess Technol., 5, 1518-1525.

Cvjetko Bubalo M., Sabotin I., Radoš I., Valentinčič J., Bosiljkov T., Brnčić M., and Žnidaršič-Plazl P., 2013. A comparative study of ultrasound, microwave and microreactor-assisted imidazolium-based ionic liquid synthesis. Green Process. Synth., 2, 579-590.

Dai J. and Mumper R.J., 2010. Plant Phenolics: Extraction, Analysis and Their Antioxidant and Anticancer Properties. Molecules, 15, 7313-7352.

Dent M., Dragović-Uzelac V., Penić M., Brnčić M., Bosiljkov T., and Levaj B., 2013. The effect of extraction solvents, temperature and time on the composition and mass fraction of polyphenols of dalmatian wild sage (Salvia officinalis L.). Food Technol. Biotechnol., 51, 84-91.

Dujmić F., Brnčić M., Karlović S., Bosiljkov T., Ježek D., Tripalo B., and Mofardin I., 2013. Ultrasound-assisted infrared drying of pear slices: textural issues. J. Food Process Eng., 36, 397-406.

Geuns J.M.C., 2003. Stevioside. Phytochem., 64, 913-921.

Ignat I., Volf I., and Popa V.I., 2011. A critical review of methods for characterisation of polyphenolic compounds in fruitsand vegetables. Food Chem., 126, 1821-1835.

Khoddami A., Wilkes M.A., and Roberts T.H., 2013. Review - techniques for analysis of plant phenolic compounds. Molecules, 18, 2328-2375.

Knorr D., Zenker M., Heinz V., and Lee D-U., 2004. Applications and potential of ultrasonics in food processing. Trends Food Sci. Technol., 15, 261-266.

Krishnaswamy K., Orsat V., Gariépy Y., and Thangavel K., 2013. Optimization of microwave-assisted extraction of phenolic antioxidants from grape seeds (Vitis vinifera). Food Bioprocess Technol., 2, 441-455.

Kroyer G.T., 1999. The low calories sweetener stevioside: stability and interaction with food ingredients. Lebensmittel, Wissen Technol., 32, 509-512.

Lagnika C., Zhang M., Nsor-Atindana J., and Tounkara F., 2014. Extension of mushroom shelf-life by ultrasound treatment combined with high pressure argon. Int. Agrophys., 28, 39-47.

Lavini A., Riccardi M., Pulvento C., De Luca S., Scamosci M., d'Andria R., 2008. Yield, quality and water consumption of Stevia rebaudiana Bertoni grown under different irrigation regimes in Southern Italy. Ital. J. Agron. / Riv. Agron., 2, 135-143.

Leja M., Mareczek G., Wyzgolik G., Klepacz-Baniak J., and Czekońska K., 2007. Antioxidative properties of bee pollen in selected plant species. Food Chem., 100, 237-240.

Lemus-Mondaca R., Vega-Galvez A., Zura-Bravo L., and Ah-Hen K., 2012. Stevia rebaudiana Bertoni, source of a highpotencynaturalsweetener:Acomprehensivereview on thebiochemical, nutritional and functional aspects. Food Chem., 132, 1121-1132. 
Liu J., Li J., and Tang J., 2010. Ultrasonically assisted extraction of total carbohydrates from Stevia rebaudiana Bertoni and identification of extracts. Food Bioprod. Process., 88, 215-221.

Miller N.J., Diplock A.T., Rice-Evans C., Davies M.J., Gopinathan V., and Milner A., 1993. A novel method for measuring antioxidant capacity and its application to monitoring the antioxidant status in premature neonates. Clin. Sci., 84, 407-412.

Miron TL., Herrero M., and Ibanez E., 2013. Enrichment of antioxidant compounds from lemon balm by pressurized liquid extraction and enzyme assisted extraction. J. Chromatography A, 1288, 1-9.

Mustafa A. and Turner C., 2011. Pressurized liquid extraction as a green approach in food and herbal plants extraction: A review. Anal. Chim. Acta, 703, 8-18.

O'Brien-Nabors L. (Ed.), 2012. Alternative Sweeteners. CRC Press Taylor and Francis Group, New York, USA.

Piasecka A., Krzemińska I., and Tys J., 2014. Physical methods of microalgal biomass pretreatment. Int. Agrophys., 28, 341-348.

Pingret D., Fabiano-Tixier A.S., Le Bourvellec C., and Renard M.G.C.C., 2012. Lab and pilot scale ultrasound-assisted water extraction of polyphenols from apple pomace. J. Food Eng., 111, 73-81.

Puri M., Sharma D., Barrow C.J., and Tiwari A.K., 2012. Optimisation of novel method for the extraction of steviosides from Stevia rebaudiana leaves. Food Chem., 132, 1113-1120.
Puri M., Sharma D., and Tiwari A.K., 2011. Downstream processing of stevioside and its potential applications. Biotech. Adv., 29, 781-791.

Ross K.A., Beta T., and Arntfield S.D., 2009. A comparative study on the phenolic acids identified and quantified in dry beans using HPLC as affected by different extraction and hydrolysis methods. Food Chem., 113, 336-344.

SAS/STAT, 2010. Ver. 9.3., SAS Institute, Cary, NC, USA.

Shukla S., Mehta A., Bajpai V., and Shukla S., 2009. In vitro antioxidant activity and total phenolic content of ethanolic leaf extract of Stevia rebaudiana Bertoni. Food Chem. Toxicol., 47, 2338-2343.

Shukla S., Mehta A., Mehta P., and Bajpai V.K., 2012. Antioxidant ability and total phenolic content of aqueous leaf extract of Stevia rebaudiana Bertoni. Exp. Toxicol. Pathol., 64, 807-811.

Sekaran T., Giridhar P., and Ravishankar G.A., 2007. Production of steviosides in ex vitro and in vitro grown Stevia rebaudiana Bertoni. J. Sci. Food Agr., 87, 420-424.

Šic Žlabur J., Voća S., Dobričević N., Brnčić M., Dujmić F., and Karlović S., 2012. Possibilities of using high intensity ultrasound technology with stevia - a review. Croat. J. Food Technol. Biotechnol. Nutr. 7, 152-158.

Tiwari B.K., O'Donnell C.P., Muthukumarappan K., and Cullen P.J., 2008. Effect of ultrasound processing on the quality and nutritional properties of fruit juices. Stewart Postharv. Rev., 4, 1-6.

Zayova E., Stancheva I., Geneva M., Petrova M., and Dimitrova L., 2013. Antioxidant activity of in vitro propagated Stevia rebaudiana Bertoni plants of different origins. Turk. J. Biol., 37, 106-113. 